\title{
Studies of pregnancy-associated murine serum proteins
}

\author{
J. Hau, P. E. Svendsen, B. Teisner and S.-E. Svehag \\ Laboratory Animal Unit and Institute of Medical Microbiology, Odense University, \\ DK-5230 Odense $M$, Denmark
}

\begin{abstract}
Summary. A pregnancy-associated murine protein (PAMP) with $\alpha_{1}$ electrophoretic mobility and an estimated molecular weight of 140000 was present in serum from pregnant and sexually mature non-pregnant females, but could not be detected in the serum of males. During pregnancy the serum concentration of $\alpha_{1}$-PAMP rose to a maximum in mid-pregnancy followed by a decline to preconception levels before parturition; the protein was also present in fetal and neonatal serum and in amniotic fluid at low concentrations.
\end{abstract}

\section{Introduction}

Four serum proteins have been associated with human pregnancy: pregnancy zone protein (PZP or SP3) (Smithies, 1959), pregnancy-specific $\beta_{1}$-glycoprotein (PSBG, SP1 or PAPP C) (Bohn \& Weinmann, 1974; Lin, Halbert, Kiefer, Spellacy \& Gall, 1974a), steroid-binding $\beta$-globulin (SB $\beta$ G or SP2) (Bohn, 1974) and pregnancy-associated plasma protein A (PAPP A) (Lin et al., 1974a). However, the physiological importance of these proteins is largely unknown.

By using antisera to the human pregnancy-associated proteins, serum samples from pregnant individuals of various other species have been examined for proteins showing immunological crossreactions with these proteins. Cross-reactions have been demonstrated between the human proteins PZP, SP1, SBBG and proteins present in serum from several monkey species (Bohn \& Ronneberger, 1973 ; Bohn \& Weinmann, 1974; Lin, Halbert \& Plasencia, 1976; von Schoultz, Stigbrand, Martinsson \& Holmgren, 1976). A protein cross-reacting with human PZP has been demonstrated in the beagle dog, and antiserum against dog PZP reacted with a protein in serum from pregnant cows and sheep (von Schoultz et al., 1976). In contrast, Bohn \& Ronneberger (1973) did not find any proteins in serum from pregnant dogs which reacted with rabbit antisera to human pregnancy proteins. A pregnancy-associated serum protein in the mink was described by Larsen, Porter \& Porter (1971) and in the rat by Beaton \& Selby (1960). Four pregnancy-associated serum proteins were detected in mice after immunization of rabbits with serum from pregnant mice and absorption of the rabbit antiserum with plasma powder from non-pregnant mice (Lin, Halbert \& Kiefer, 1974b).

In the present study, serum samples from pregnant and non-pregnant mice were examined in a search for an animal model which would be suitable for immunochemical and biological studies of pregnancy-associated proteins.

\section{Materials and Methods}

\section{Animals}

Outbred SPF mice of the strain NMRI/BOM were used. Conception time was determined by the presence of a vaginal plug, and designated Day 1 of pregnancy. Small blood samples were obtained by periorbital or tail-vein puncture, larger samples by heart puncture in animals anaesthetized by intraperitoneal injection of sodium pentobarbitone (Nembutal: Abbott). Antibodies were raised in conventional albino rabbits (State Serum Institute, Copenhagen) which were bled by puncture of the marginal ear vein. 


\section{Production of antisera}

Pooled serum from 11-15-day-pregnant mice was fractionated by gel filtration chromatography on a column (Pharmacia K 26/100) packed with Sephadex G-200 (Pharmacia). The column was kept at $10^{\circ} \mathrm{C}$ and equilibrated with $0.05 \mathrm{M}$-sodium phosphate buffer. The flow rate was $10 \mathrm{ml} / \mathrm{h}$. The separation profile consisted of three major peaks, and the fractions from each of these were pooled, concentrated, mixed with Freund's incomplete adjuvant and injected intradermally into rabbits, at doses of $400 \mu \mathrm{g}$ protein, every 2 weeks.

The rabbit antiserum was absorbed with a 10-30\% volume of a pool of serum from male mice for $24 \mathrm{~h}$ and ultracentrifuged at $70000 \mathrm{~g}$ for $1 \mathrm{~h}$. The supernatant was tested for antibody activity by crossed immunoelectrophoresis against serum from pregnant mice and male mice.

\section{Quantitative and analytical electroimmunoassays}

Rocket electrophoresis (Laurell, 1972) was performed on $11 \times 20 \mathrm{~cm}$ glass slides in a $1 \%$ agarose gel with a barbital/barbital sodium buffer, ionic strength 0.020 , pH 8.6 , at $2.5 \mathrm{~V} / \mathrm{cm}$ for $18 \mathrm{~h}$. The wells received $5 \mu \mathrm{l}$ serum. One arbitrary unit (AU) of $\alpha_{1}$-PAMP (pregnancy-associated murine protein) refers to the amount of $\alpha_{1}$-PAMP present in $1 \mathrm{ml}$ of a standard serum pool from non-pregnant female mice, diluted $1: 150$ in $0.9 \%(w / v) ~ N a C l$ solution.

Crossed immunoelectrophoresis was performed with the same gel-buffer system. The first dimension electrophoresis was run at $10 \mathrm{~V} / \mathrm{cm}$ for $1.5 \mathrm{~h}$ and the second at $2.5 \mathrm{~V} / \mathrm{cm}$ for $18 \mathrm{~h}$.

The electrophoretic mobility of the proteins was estimated by crossed immunoelectrophoresis and by using a human reference serum in the same first dimensional run as the murine antigen. The positions of the reference proteins $\alpha_{1}$-antitrypsin, complement factor 3 and pregnancy zone protein were indicated by the use of monospecific antisera (DAKO-Immunoglobulins, Copenhagen, Denmark, and Institute of Medical Microbiology, Odense University).

\section{Molecular weight estimation}

An Ultrogel ACA 34 (L'Industrie Biologique Française) column (Pharmacia K 26/100) equilibrated with $0.05 \mathrm{M}$-sodium phosphate buffer was used and a standard curve was established from chromatographic constant $\left(K_{\mathrm{av}}\right)$ values calculated for 5 different proteins of known molecular weight; chymotrypsinogen A (25000), egg albumin (45000), bovine serum albumin $(67000)$, aldolase $(158000)$ and catalase $(240000)$, by using the formula $K_{\mathrm{av}}=\left(V_{\mathrm{e}}-V_{\mathrm{o}}\right) /\left(V_{\mathrm{t}}-V_{\mathrm{o}}\right)$, where $V_{\mathrm{e}}=$ elution volume for a given protein, $V_{\mathrm{t}}=$ total bed volume and $V_{\mathrm{o}}=V_{\mathrm{c}}$ for blue dextran. The molecular weights of $\alpha_{1}$-PAMP and $\alpha_{2}$-PAMP were estimated by determination of their $K_{\mathrm{av}}$ values and interpolation from the standard curve.

\section{Results}

\section{Production of antisera against murine pregnancy associated proteins}

After fractionation of serum from 11-day-pregnant mice by Sephadex G-200 gel filtration, three pools of proteins were prepared from the high molecular, the intermediate and the low molecular part of the protein profile. Rabbits were given 4-6 intradermal injections of material from each of the three pools of the protein elution profile. After immunization with the intermediate pool an antiserum was obtained, which, following absorption with male murine serum, retained antibody activity against two $\alpha$-mobile pregnancy-associated proteins. This antiserum produced a single precipitate in crossed immunoelectrophoresis when serum from non-pregnant mice was used as antigen, but two precipitates when serum from pregnant mice was included as antigen ( $\mathrm{Pl}$. 1, Fig. 1). By using this absorbed antiserum in rocket electrophoresis and fractions from ACA 44 gel filtrations of serum from mice in mid- and late-pregnancy as antigen, it was possible to separate the two proteins with $\alpha$ mobility.

\section{Electrophoretic mobility and molecular weight estimation}

The electrophoretic mobilities of the two murine proteins were compared with those of three human proteins of known electrophoretic mobility ( $\alpha$-1-antitrypsin, PZP and complement factor 3 ) 
PLATE 1

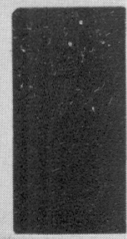

2
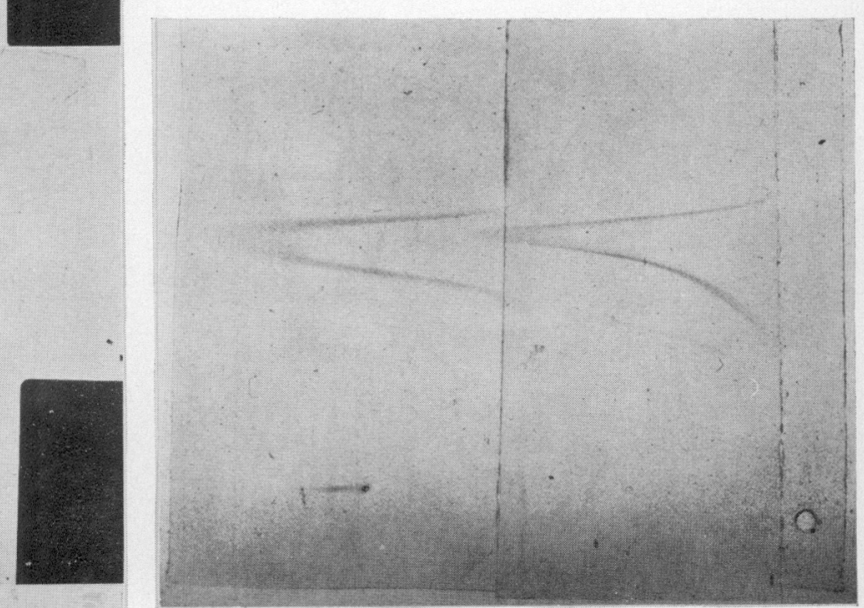

离

点

घं च

चु

당

을

牚

듬

岕的

苛点

忽犃

ฐ

$\Xi \quad$

为

ठํㅛ

เั

है ह

E

훈 뭉

E

린롱

矛造宫

워

원혀

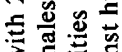

ह

论

은 늘

究包

त

툴을

웡 응

氙 텅

N

는

요용

它氖

至范。

\&

3.80

늘

它志的

동

은은

造察宽

三品

ᄅี हี

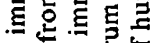

记

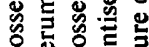




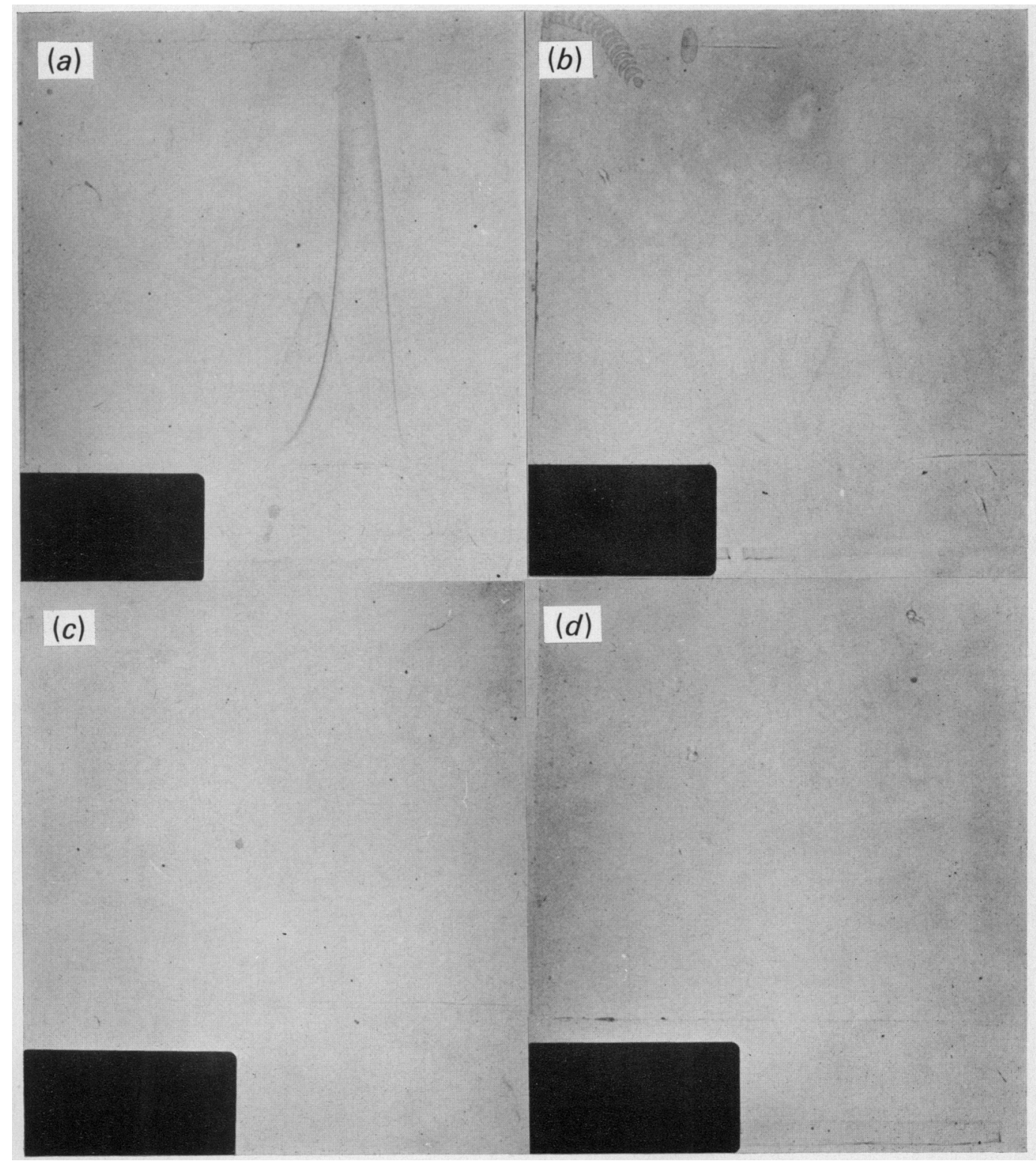

Fig. 3. Crossed immunoelectrophoresis with rabbit antiserum absorbed with $23 \%$ murine male serum (a,d), $33 \%$ nonpregnancy serum (b) and 11-day-pregnant serum (c) in the second dimensional gels. The antigen was 11-day-pregnant serum in (a), (b) and (c) and male serum in (d). 
by crossed immunoelectrophoresis in which human and murine serum were used in the first dimension. Plate 1, Fig. 2 demonstrates the comparison between the electrophoretic mobilities of $\alpha_{1}$-PAMP and $\alpha_{1}$ antitrypsin. Because of their mobilities, the two murine proteins were named $\alpha_{1}-P A M P$ and $\alpha_{2}$-PAMP. For the calculation of their molecular weights the following values were used: $V_{t}=438.0 \mathrm{ml}$ and $V_{0}=153.3 \mathrm{ml}$ and the $K_{\mathrm{av}}$ was 0.40 for $\alpha_{1}$-PAMP and 0.47 for $\alpha_{2}$-PAMP. The molecular weights of $\alpha_{1}$-PAMP and $\alpha_{2}$-PAMP were estimated by reference to the standard curve based on the five marker proteins (Text-fig. 1) and were 140000 and 70000 respectively.

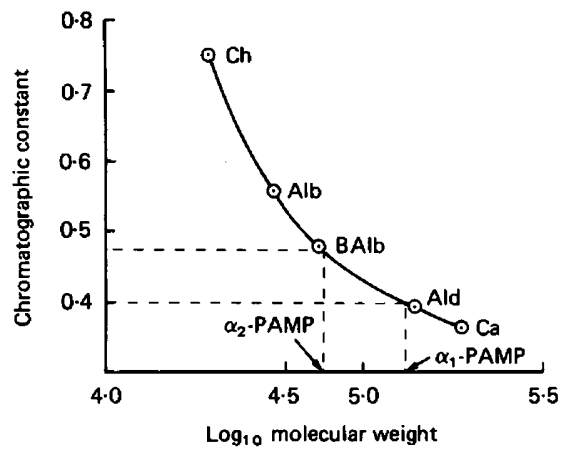

Text-fig. 1. Molecular weight of the two mouse serum proteins estimated by the use of an Ultrogel ACA 34 column and the marker proteins chymotrypsinogen (Ch), egg albumin (Alb), bovine serum albumin (BAlb), aldolase (Ald) and catalase (Ca).

\section{Differentiated absorption of rabbit antiserum against $\alpha_{1}-P A M P$ and $\alpha_{2}-P A M P$}

The antibody activities of the dispecific rabbit antiserum were not affected by absorption with murine male serum, but absorption with serum from non-pregnant female mice abolished the antibody activity against $\alpha_{1}$-PAMP, leaving the activity against $\alpha_{2}$-PAMP unaltered. The antibodies against both proteins were absorbed when serum from 11-day-pregnant mice was used (Pl. 2, Fig. 3).

Table 1. The mean \pm s.e.m. (no. of samples in parentheses) concentrations of $\alpha_{1}$-PAMP in serum and amniotic fluid of mice

\begin{tabular}{lc}
\hline & $\begin{array}{c}\text { Conc. of } \alpha_{1} \text {-PAMP } \\
\text { (arbitrary units/ml) }\end{array}$ \\
\hline Non-pregnant adult females & $196 \pm 14(67)$ \\
Mid-pregnant females & $1098 \pm 132(7)$ \\
Females at term & $82 \pm 27(12)$ \\
Post-partum females & $174 \pm 27(13)$ \\
Adult males & $0 \pm 0(37)$ \\
Fetus & $1 \mp 0 \cdot 3(16)$ \\
Amniotic fluid & $4 \pm 1(14)$ \\
Newborn young (<2 days) & $0 \cdot 5 \pm 0 \cdot 2(32)$ \\
Juvenile females (3-14 days) & $0 \pm 0(14)$ \\
& \\
\hline
\end{tabular}

\section{Concentrations of $\alpha_{1}-P A M P$}

It was possible to detect $\alpha_{1}$-PAMP by electroimmunoassays in serum from pregnant mice, nonpregnant adult female mice, fetal serum, amniotic fluid and serum from infant mice until 2 days of age, but it could not be detected in serum of males and juvenile females (3-14 days of age). The $\alpha_{1}$-PAMP concentration was significantly higher $(P<0.001$, Student's $t$ test $)$ in 11-day-pregnant mice than in non-pregnant adult females or in pregnant females shortly before term, and very low in amniotic fluid, fetal serum and neonatal serum (Table 1). 
A total of 231 serum samples was obtained from 58 primigravid mice and the changes of concentration of $\alpha_{1}$-PAMP are shown in Text-fig. 2 . By the 4 th day after conception the concentration was significantly higher than values before conception $(P<0.001$, Student's $t$ test $)$ and it remained elevated until the 17th day of pregnancy $(P<0.001)$. At the time of parturition the serum level had fallen but was not significantly lower than that in non-pregnant females. The post-partum $\alpha_{1}$-PAMP concentrations were similar to the values before conception.

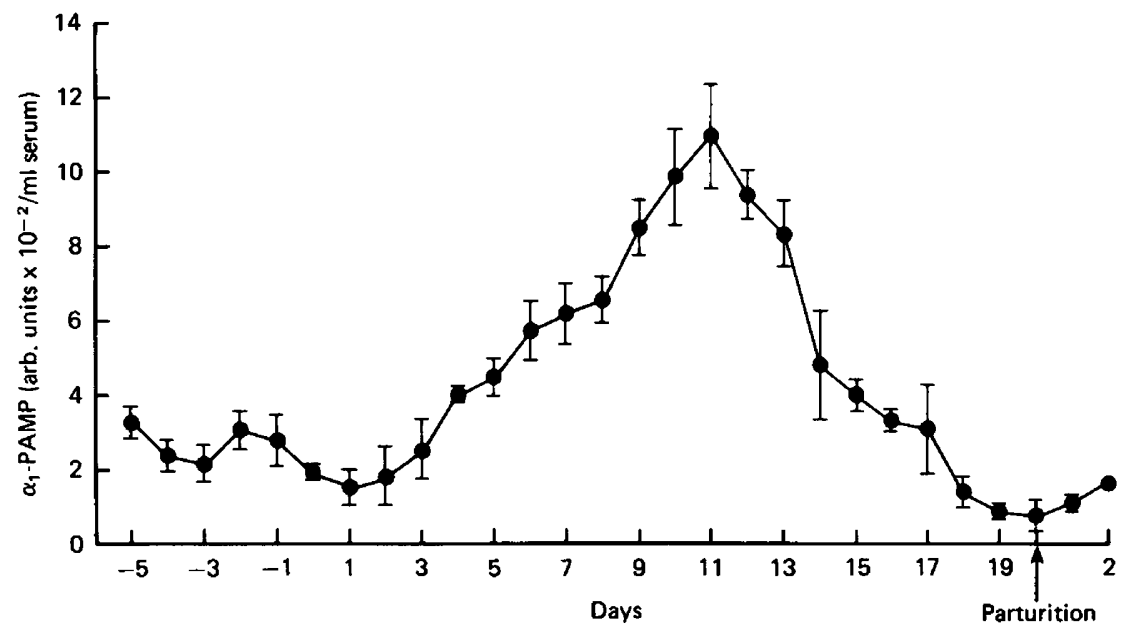

Text-fig. 2. The concentrations of $\alpha_{1}$-PAMP, measured by rocket immuno electrophoresis, in 231 serum samples from 58 primigravid mice. Values are mean \pm 1 s.e.m. for 5-15 samples at each point.

Cross-reactivity between $\alpha_{1}-P A M P$ and proteins present in serum from pregnant individuals of other species

Serum samples from pregnant and non-pregnant women, cows, pigs and rats were tested for proteins cross-reacting with $\alpha_{1}$-PAMP by using the rabbit antiserum to $\alpha_{1}$-PAMP. No such crossreacting proteins were detected in serum from pregnant women, cows and pigs. However, serum from pregnant and non-pregnant rats, but not male rats, contained a protein which cross-reacted with $\alpha_{1}$-PAMP.

\section{Discussion}

Antiserum against two murine pregnancy proteins has been produced. The $\alpha_{1}$-PAMP also appears to be present in low concentrations in the serum from non-pregnant adult females and may be defined as a pregnancy-associated protein. The $\alpha_{2}$-PAMP seems to be present only during pregnancy and is tentatively considered to be a pregnancy-specific protein. These findings suggest that $\alpha_{1}$-PAMP is not identical to any of the four proteins demonstrated by immunodiffusion by Lin et al. (1974b). In their undifferentiated absorption of the rabbit anti-mouse pregnancy serum with plasma powder from non-pregnant mice one would expect a removal of all antibodies against $\alpha_{1}$-PAMP. This could also explain why Lin et al. (1974b) did not observe any cross-reaction between proteins in rat serum and pregnancy-associated mouse proteins. The $\alpha_{1}$-PAMP seems to be related to the female reproductive cycle, because it does not occur in juvenile females 3-14 days of age or in males at any age. Furthermore, the presence of the protein in fetal and neonatal serum and in amniotic fluid, in low concentrations, indicates a transplacental transfer.

The protein differs from human SP1, which appears only during pregnancy and not in nonpregnant women (Bohn \& Sedlacek, 1975). In contrast, human PZP and SBBG are both, like $\alpha_{1}$ PAMP, present in the serum of non-pregnant females. 
Comparison of the serum levels of $\alpha_{1}$-PAMP and the human pregnancy-associated serum proteins shows that the former is characterized by a rapid increase in serum concentration reaching maximum value at mid-pregnancy, followed by a rapid decline to preconception concentrations before parturition. All the human pregnancy-associated serum proteins increase rather slowly in concentration and reach their maximum in the last trimester, followed by a post-partum decline to values in nonpregnant women (Towler, Jandial \& Horne, 1976; Lin \& Halbert, 1975). Further investigation of the murine pregnancy-associated proteins is necessary before a comparison between the two species can be made.

\section{References}

BeAton, G.H. \& Selby, A. (1960) A new serum protein in pregnant rats. Fedn Proc. Fedn Am. Socs exp. Biol. 19, 74.

BoHN, H. (1974) Quantitative immunologische Bestimmung von $\boldsymbol{\alpha}_{2}$ AP-Glykoprotein $\left(\mathrm{SP}_{3}\right)$ und vergleichende Untersuchungen über das Steroidbindende $\beta$-Globulin $\left(\mathrm{SP}_{2}\right)$ Behring Inst. Mitt. 54, 56-67.

BOHN, H. \& RONNEBERGER, H. (1973) Immunologischer Nachweis von Schwangerschaftsproteinen des Menschen im Serum trächtiger Tiere. Arch. Gynäk. 215, 277-284.

Bohn, H. \& SedlaceK, H. (1975) Eine vergleichende Untersuchung von placentaspezifischen Proteinen bei Mensch und subhumanen Primaten. Arch. Gynäk. 220, 105-121.

BOHN, H. \& WEINMANN, E. (1974) Immunologische Unterbrechung der Schwangerschaft bei Affen mit Antikörpern gegen das menschliche schwangerschaftspezifische $\beta_{1}$-Glykoprotein $\left(\mathrm{SP}_{1}\right)$. Arch. Gynäk. 217, 209-218.

Larsen, A.E., Porter, D.D. \& Porter, H.G. (1971) Pregnancy-associated serum protein in mink. Proc. Soc. exp. Biol. Med. 136, 430-432.

LAURELL, C.-B. (1972) Electroimmuno assay. Scand. J. clin. Lab. Invest. 29, Suppl. 124, 21-37.
LiN, T.-M. \& Halbert, S.P. (1975) Immunological comparison of various human pregnancy-associated plasma proteins. Int. Arch. Allergy appl. Immunol. 48, 101-115.

Lin, T.-M., Halbert, S.P., Kiefer, D., Spellacy, W.N. \& GALl, S. (1974a) Characterization of four human pregnancy-associated plasma proteins. Am. J. Obstet. Gynec. 118, 223-236.

LiN, T.-M., Halbert, S.P. \& Kiefer, D. (1974b) Pregnancy-associated serum antigens in the rat and mouse. Proc. Soc. exp. Biol. Med. 145, 62-66.

Lin, T.-M., Halbert, S.P. \& Plasencia, R. (1976) Pregnancy zone protein analogue in pregnant and non-pregnant primates, and its decrease during pregnancy in some monkey species. Clin. exp. Immunol. 26, 609-622.

Smithies, O. (1959) Zone electrophoresis in starch gel and its application to studies of serum proteins. Adv. Protein Chem. 14, 65-111.

TOWler, C.M., JANdial, V. \& HoRNe, C.H.W. (1976) A serial study of pregnancy proteins in primigravidae. Br.J. Obstet. Gynaec. 83, 368-374.

Von Schoultz, B., Stigbrand, T., Martinsson, K. \& HolmgreN, N. (1976) Demonstration of analogues to the human pregnancy zone protein in animals. Acta endocr., Copenh. 81, 379-384.

Received 30 December 1977 